This item was submitted to Loughborough's Research Repository by the author.

Items in Figshare are protected by copyright, with all rights reserved, unless otherwise indicated.

\title{
Three models of republican rights: Juridical, parliamentary and populist
}

PLEASE CITE THE PUBLISHED VERSION

https://doi.org/10.1177/0032321716648339

PUBLISHER

SAGE Publications

VERSION

AM (Accepted Manuscript)

\section{PUBLISHER STATEMENT}

This paper was accepted for publication in the journal Political Studies and the definitive published version is available at https://doi.org/10.1177/0032321716648339. Users who receive access to an article through a repository are reminded that the article is protected by copyright and reuse is restricted to non-commercial and no derivative uses. Users may also download and save a local copy of an article accessed in an institutional repository for the user's personal reference.

\section{LICENCE}

CC BY-NC-ND 4.0

\section{REPOSITORY RECORD}

Aitchison, Guy. 2016. "Three Models of Republican Rights: Juridical, Parliamentary and Populist". Loughborough University. https://hdl.handle.net/2134/15059694.v1. 


\title{
Three Models of Republican Rights: Juridical, Parliamentary and Populist
}

\author{
Dr. Guy Aitchison \\ g.aitchison@lboro.ac.uk
}

Published in: Political Studies, Volume 65, Issue 2

DOI: $10.1177 / 0032321716648339$ psx.sagepub.com

This is a pre-publication draft.

Accepted 31 March 2016.

\begin{abstract}
The republican tradition in political theory offers a distinct approach to thinking about rights that addresses long-standing objections to the depoliticising logic of the discourse through its attention to power relations and the socially embedded nature of moral claims. However, the most systematic republican theories of rights-based citizenship translate these theoretical commitments into a tame set of institutional proposals that largely affirm existing states. In this article, I critique the limits of Philip Pettit's juridical republicanism and Richard Bellamy's parliamentary republicanism and set out an alternative populist account of republican citizenship based on the notion of rights as 'claims' - a form of speech act that empowers agents with self-respect to mobilise popular support and challenge arbitrary power when political institutions are unresponsive or unavailable. Populist citizenship takes place whenever social groups and classes mobilise directly outside constitutional structures in order to contest the legitimacy of the political regime and lay claim to new rights through direct appeal to the sovereign authority of the people themselves.
\end{abstract}

A recurring criticism of the discourse of rights is that its orientation towards purportedly decisive moral norms detracts from the cold, hard facts of political life in potentially counterproductive and anti-democratic ways. Abstract appeals to natural law, human dignity or whichever foundational norm is thought to ground rights, critics say, detract from the difficult practical questions of how rights are implemented in real-world political societies marked by pluralism and disagreement, material scarcity, weak and corrupt institutions and entrenched social hierarchies. In contemporary political theory, this concern with the depoliticising logic of rights underlies a number of different theoretical projects and perspectives. It can be found in the writings of neo-Kantians who argue that universal proclamations of human rights are 'hollow' without attention to how the corresponding duties are to be institutionally enforced (James, 2003; O'Neill, 2000); theorists of human rights sensitive to the role the concept plays in international affairs (Beitz, 2009; Raz, 2010); and radical critics who seek to unmask the concept's ideological role in naturalising capitalist social relations beyond collective 
contestation (Brown, 2004; Douzinas, 2000). While these critiques differ in their motivations and substantive conclusions, they share a common scepticism towards a form of rights-based liberalism that treats rights as the moral property of isolated individuals, which can be traced back to early theoretical opponents of natural rights (Waldron, 2014).

This article examines how republicanism - a tradition of thought centrally concerned with political action and participation - can contribute to our understanding of the political nature of rights and how they are best realised and protected in contemporary societies. Although the dominant 'neo-Roman' school of republican thought - distinguished by its 'negative' view of freedom as non-domination or non-dependency (Pettit, 1997: 40; Skinner, 1998) - does not deny the existence of individual rights, leading exponents have been critical of the dominant approach to rights within modern liberal theory. Modern liberals are accused of focusing on the demand-side of rights to the neglect of the supplyside, generating ever longer lists of individual moral entitlements with insufficient attention to the institutional and civic preconditions necessary to secure equality and freedom from the ever-present threat of arbitrary power. In their more polemical moments, leading exponents of the neo-Roman school have condemned the 'corrupt' logic of liberal rights theory, which is linked to a selfregarding form of individualism appropriate to today's fragmented and competitive commercial culture (Skinner, 1986: 243). Although some republicans emphasise the commonalities between liberal and republican thought (Dagger, 1997; Habermas, 1994), a key difference remains between the characteristically liberal idea of rights as protections for a pre-political form of natural freedom and the republican view of rights as the historical outcome of a political community's efforts to establish and maintain its freedom under the rule of law.

Despite these apparent tensions, it is striking how the most systematic republican theories of rights-based citizenship closely resemble those of mainstream liberal theory: republican theorists arrive at a similar set of political and constitutional prescriptions to those of liberals, albeit from different premises. The result is a set of institutional recommendations familiar from contemporary liberal states that vitiates the democratic and egalitarian potential of a republican approach to rights. For juridical republicans, such as Philip Pettit, it is possible to identify an authoritative set of rights that warrant protection outside the democratic process. Pettit therefore recommends a constitutional bill of rights overseen by courts which provide a forum for individuals to check and test the decisions of democratic majorities, conceived as the ultimate source of arbitrary power.1 For parliamentary republicans, such as Richard Bellamy, the contested nature of rights among citizens entails that judicial authority over their content may itself be partisan and hence arbitrary. This translates to a commitment to representative legislatures with sovereign decision-making authority in line with the 'Westminster' model of constitutionalism.2 In their focus on constitutional design and procedure, these accounts operate with a circumscribed view of politics. There is little space in either approach for the role of non-institutional forms of popular struggles as a creative source of norms and as a counter-veiling force to corrupt and dysfunctional institutions, despite the prima facie importance of these struggles to the achievement of many of the canonical rights we value today.

This article sets out a populist account of republican citizenship that responds to this oversight and accounts for the frequently restive, agonistic character of rights politics. Populist 
citizenship takes place whenever social groups and classes mobilise directly outside constitutional structures in order to contest the legitimacy of the political regime and lay claim to new rights through direct appeal to the sovereign authority of the people themselves. The vital role of popular mobilisation as a guarantor of rights has been recognised by canonical republican thinkers, from the seventeenth-century English Levellers to the American and French revolutionaries. The second amendment to the US constitution on the right to bear arms (however destructive and anachronistic its application in today's context) acknowledged the fundamental link between freedom and popular power, while the 1789 draft of the French Declaration of the Rights of Man even included alongside 'freedom, property and security', the right of 'resistance to oppression'. This was removed from subsequent drafts of the Declaration and although it has made sense from the perspective of later governments to deny constitutional recognition to such a right, popular struggle still exists as a shadowy presence that underlies the official constitutional order. While the prospect of revolution has subsided, vigorous contestation by popular movements remains a vital means for the achievement and enforcement of rights given the limitations of formal citizenship (Fox Piven, 2006; Tilly, 2012).

In this article, I first set out the contribution of republican thought to our understanding of the nature and function of rights as a political concept. This is followed by a critical examination of juridical republicanism, represented by Pettit's work, and parliamentary republicanism, as proposed by Bellamy. I then set out an account of populist politics based on the notion of rights as 'claims', a form of speech act that empowers agents with selfrespect to mobilise popular support and challenge arbitrary power when political institutions are unresponsive or unavailable. In making this argument, I draw on recent revisions of republicanism that emphasise the productive role of social antagonism in political life (McCormick, 2011) and the structural nature of domination - which exists despite the possession of formal rights through the corrupting effects of economic inequalities (Gourevitch, 2014) and systematic patterns of cultural exclusion and marginalisation (Krause, 2013; Laborde, 2008). I conclude with an illustration of populist republican citizenship taken from contemporary popular movements for a right to housing.

\section{Rights and Republicanism}

In what follows, I offer a general characterisation of how republican commitments shape thinking on rights, noting the key points of difference with liberalism. The presentation is stylistic, bracketing for now important differences internal to the two traditions and the argumentative underpinnings of the authors' views in order to identify what is distinctive about the republican contribution, according to its leading proponents. I do not consider therefore whether particular republican criticisms point to a fundamental theoretical break with liberal rights theory or - as some have claimed - simply a difference in emphasis. 3 While a number of critics have faulted liberal theories of rights for their 'individualism' (see, for example, Macpherson, 1969), this critique takes a specific, more limited form in republican argument. Morally speaking, rights are individualistic in the sense that they attach themselves subjectively to individuals and serve their interests above those of abstract communal entities. 4 It is not, however, this fact about rights that republicans object to. The pre-eminent neo-Roman school of republicanism, which I focus on in this article, shares the moral individualism of those liberals who reject the doctrine of 'positive' liberty faulted by Isaiah 
Berlin (Laborde and Maynor, 2008). However, republicans question the ontological presuppositions of some liberal approaches: the particular conception of the rights-bearing individual. Specifically, republicans object to an atomistic conception of the individual divorced from social ties and an understanding of psychological motivation that focuses on an individual's self-regarding concern with private affairs over their capacity to care for and uphold the common good.

These objections can be understood with reference to the competing conceptions of freedom of the two traditions, which is a central disagreement with liberalism highlighted by leading exponents of republicanism, such as Philip Pettit. Under the neo-Roman conception of freedom, an agent is free to the extent that they enjoy robust protection from the arbitrary interference of another agent in their choices. A free person is one who enjoys the upright social standing that comes with not being vulnerable to the capricious will of others (Pettit, 1997: 99). This contrasts with the more atomistic view of freedom as non-interference attributed to liberals, which calls attention not to the character of an agent's relationships with others but to the scope of the domain of action in which they are not constrained. While for republicans freedom is a political status we have as selfdetermining citizens under the rule of law, for liberals, the paradigm of a free person is one who is free to pursue their own private ends unobstructed. Accordingly, republicans object to liberal conceptions of rights which, in a hangover from early modern social contract theory, understand rights as a form of moral property that protects a pre-political form of freedom. Elements of this view can be found in Ronald Dworkin's notion of rights as 'trumps' (1977) and (most conspicuously) in Robert Nozick's (1974) theory of natural rights as 'side constraints'. And while John Rawls (1971: 239) was careful to stress that freedom is only secured by a structure of institutionally defined rights and duties, he nonetheless draws criticism from republicans for treating the 'basic liberties' as somehow removed from concrete processes of political legitimation on the basis of their hypothetical contractual endorsement (Bellamy, 2007; Pettit, 2012). For republicans, political society does not exist to enforce a set of transcendent and pre-existing rights. Rather, rights themselves are a product of political agreements among citizens about how political power is to be controlled and restrained (Sunstein, 1988).

The liberal philosophical project of morally 'deriving' rights from the purportedly universal interests or attributes of persons can mislead us into thinking about the concept in abstract terms as a two-part structure of ' $A$ has a right to $X$ ', where $A$ refers to the rights-bearing agent and $X$ to the content of their right, such as free speech or property (see, for example, Gewirth, 1982). By contrast, republicans will emphasise that rights are a three-part relationship, involving some further agent - agent ' $B$ ' - who bears the corresponding obligation to secure $A$ in the enjoyment of $X$ (Bellamy, 2012: 451). To bring obligation-bearers into focus has important implications since it draws our attention to the fact that rights rely on the support and co-operation of others for their enforcement. While some liberals have offered influential arguments for a focus on obligations as a corrective to the inflated moral 'rhetoric' of rights (O'Neill, 2000), this focus takes a distinctive form among republicans who have been concerned with the security of rights and how the potential conflicts they give rise to should be politically resolved. Agent B will have opinions and interests of their own, including their own rights. Thus, republicans stress that rights clash with one another and with other legitimate concerns for the well-being, security and prosperity of society as a whole (the res publica or common good). The fundamental issues of principle raised by rights generate 
inevitable disagreement and conflict, which no appeal to nature, reason or some other prepolitical legitimating principle can definitively settle. This perspective need not commit republicans to the positivist Benthamite conclusion that the only true rights are those found in law and social convention while any talk of moral rights is meaningless. It is perfectly coherent to think that there is some objective 'truth' to our moral disagreements about rights, but that we lack any agreed epistemological criteria to adjudicate on who is correct in some ultimate sense that would warrant the removal of rights from politics (Bellamy, 2007; Waldron, 1999). Any moral basis for rights is to be treated as historical and provisional, the product of a particular community's ongoing efforts to constrain the powerful and promote the common good. Notably, republicans care not only about the existence of interference but also about its very possibility: an agent is unfree if another has the capacity for arbitrary interference in their choices even if that capacity is not exercised, a point illustrated with reference to the slave with the benign non-interfering master (Pettit, 1997; Skinner, 1986). The republican preoccupation with practical enforcement is therefore relatively demanding since it extends to cases where there is the mere potential for rights being undermined. Certainly, there are many historical and contemporary liberals who have echoed the republican concern for a vigilant and active citizenry, seeing political participation - up to the point of civil disobedience and resistance - as vital to the defence of rights. Nonetheless, within republicanism there is a definite orientation to thinking about the legal, political and cultural preconditions to make such participation effective across time.

A further contribution has been to highlight the dual moral character of rights. It is part of the socially embedded nature of rights, for republicans, that their moral justification does not refer exclusively to the good of individuals, but has a public dimension in making reference to shared projects: the moral good of the individual is inextricably tied to the fate of the political community as a whole. This is true of the right to privacy, for example, which is valued not merely for the reasons characteristically given by liberals, such as the individual interest in controlling one's social identity (Marmor, 2015), but as a pre-requisite for political autonomy and effective participation in political processes that will make privacy (and other rights) more secure (Roberts, 2015). It follows that the notion of the independent and autonomous 'lone rights-bearer' is condemned by republicans as both descriptively false and morally perverse (Glendon, 2008: 47-76). This has normative implications with regard to what characteristics, motivations and behaviours are desirable for democratic citizens (the so-called civic virtues). For republicans, to insist upon one's rights without regard for how this affects the public interest undermines the ethos of community and solidarity that underpins a free society. As Quentin Skinner argues, to defend one's own private rights against all outside interference is a 'corrupt' form of citizenship; not only a dereliction of one's duty to the common good, but an imprudent neglect of the conditions that make one's own freedom possible (Skinner, 1986: 243).

A final point concerns how republicans understand the 'standard threats' to rights (Shue, 1996: 13). The conception of freedom as non-domination is a broad - and potentially very radical - notion that applies to any relations where individuals are in a state of systematic dependence and vulnerability (Laborde and Maynor, 2008). Accordingly, republicans can be expected to care about the threats to rights not just from the state, but from private sources of dominating power, including the family, workplace and other spheres of life, including those not currently identified as 'political'. To summarise, republicans call attention to the 
normative and conceptual features of rights that embed them firmly within politics: rights are relational (rather than atomistic), active (rather than possessive), contested (rather than natural), limited (rather than absolute) and dualistic in promoting (rather than merely trumping) the common good alongside the good of individuals. The idea of rights cannot preempt politics for republicans, since rights themselves are only given meaning and content through political association, requiring ongoing participation by virtuous citizens who defend and enforce their freedom against both private and public sources of dominating power. I now turn to examine how the preeminent accounts of citizenship in the contemporary republican literature give expression to these theoretical commitments.

\section{Pettit and Juridical Republicanism}

Across a number of works, Pettit has developed a rich and systematic account of the laws and political institutions of a republican polity based on his finely tuned theory of freedom as nondomination. While Pettit (1996: 173) stresses that the specific institutions that instantiate non-domination within a given society will vary according to local empirical realities, there are nonetheless some core theoretical features to his model based on the ideals of a 'mixed constitution' and a 'contestatory citizenry'. Here, freedom is understood as the equal juridical status citizens enjoy under the rule of law in contrast to freedom as participation or selfgovernment which Pettit associates with 'populist' traditions of republicanism. In Pettit's model, citizens are both 'authors' of the law through democratic elections to representative legislatures and 'editors' of the law who check and test it against their interests and the common good to ensure it is non-dominating (Pettit, 2004). A central concern is with how to check the 'popular passion, aspirational morality and sectional interests' (Pettit, 2004: 54) of majoritarian politics, which is treated as the 'ultimate' source of arbitrary power (Pettit, 1997: 9). This requires, for Pettit, a system of tribunals, monitoring bodies and a constitutional bill of rights that takes certain issues off the political agenda entirely by empowering courts to review - and potentially invalidate - laws deemed to contravene those rights.

Pettit has drawn criticism for the elitist character of his institutional proposals, which would constrain the democratic powers of political majorities by handing powers to judges and other technocrats and experts (McCormick, 2011). John McCormick (2011) identifies Pettit's approach with an 'aristocratic' tradition of republicanism that feared the political power of majorities to challenge inegalitarian distributions of private property, highlighting a counterMachiavellian tradition in which the passion and antagonism of the popular classes is a vital means to protect freedom from a wealthy oligarchic elite. Machiavelli's emphasis on classbased antagonism speaks to contemporary concerns at the domination of politics by the rich (Winters, 2011). In a number of jurisdictions - including in supra-national polities, such as the European Union - the depoliticisation of rights has been a favoured means for economic and political elites to entrench policies that favour free markets, private property and austerity against democratic challenge (Nicol, 2010). This is not to say that Pettit ignores the threat of oligarchic power. He proposes various reforms to media ownership, lobbying and party funding to prevent the corruption of politics by monied influence (Pettit, 1997: 160-170). Moreover, in his discussion of republican social justice, he argues that citizens must be effectively 'resourced' with a robust set of social rights that secure them against exploitation, manipulation and intimidation by the wealthy and identifies specific legal 'protections' that enhance the power of employees and other potentially vulnerable groups (Pettit, 2012: 75- 
129). There are good reasons to think that republican justice so conceived would still leave in place objectionable inequalities that do not involve domination (Southwood, 2015). However, my disagreement here is not with the substance of the specific rights Pettit proposes, but with his limited and conservative account of the political processes through which they are created, enforced and upheld.

Notably, Pettit's recent restatement of his theory highlights the more democratic and collective character of contestation. Although he continues to recommend a system of courts and other constitutional restraints, he no longer talks of 'depoliticising' rights. Echoing Machiavelli, he acknowledges the need for an 'active, engaged style of politics' and a 'restive' political culture so that democratic life has an 'agonistic' or even an 'antagonistic' character (Pettit, 2012: 216). This is grounded in a 'political ontology' that affirms the ultimate priority of the plurality of citizens active in self-government (the 'constituting people') over the singular corporate entity of the state responsible for law and policy ('the constituted people') (Pettit, 2012: 280-292). This affirmation of popular power, however, is in tension with the overall thrust of Pettit's work, which is concerned with the optimal constitutional procedures through which to channel popular participation and the negative, checking role of contestation in defence of established legal claims. Pettit's focus on the editorial role of citizenship follows from his account of non-domination, which leads him to assume that it is a matter of common knowledge whether power is 'arbitrary' (Pettit, 1997) or 'uncontrolled' (Pettit, 2012). The powerful are conscious of their domination of subordinates who are aware of their subjection and can challenge it through appeal to public values. This underpins Pettit's discussion of the question of 'sticky' minorities who are susceptible to discriminatory measures by democratic majorities in the absence of constitutional rights. Pettit (2012: 212) assumes that it is possible to identify ex ante minorities who are 'more or less bound to be on the losing side' in democratic decisions on account of their identity. As a number of theorists have pointed out, the difficulty with this picture is that it overlooks domination that is reproduced through the unconscious reproduction of social norms, habits and behaviours so that the denial of rights to a particular social group is invisible as a matter of public concern (Krause, 2013). Conceived in this way, the task of politics is not simply about the protection and progressive extension of acknowledged rights through appeal to shared norms, but the definition and authorship of new claims.

While Pettit stresses the potential for innovation within his vision of a deliberative republic, the process he describes notably relies on the progressive unfolding of moral reason with little space for the creative and unsettling role of political action outside the prescribed channels. Thus, the achievement of rights by workers, women and other excluded groups in Britain over the course of the nineteenth century - which Pettit (2012: 254) discusses by way of illustration - follows in a teleological fashion from the prior articulation of egalitarian norms which had a 'slow, relentless effect on how government operated, pushing it inexorably towards a certain direction'. Accordingly, the role of social movements is understood along deliberative lines as bringing reasons and arguments into the public sphere and civil disobedience is conceived in a mild, formalised sense as a way of opposing laws 'within the system' (Pettit, 2012: 137-138). At various points, Pettit speaks of the 'right of resistance', which, more than any other right, is said to establish the ultimate authority of the constituting people over the state. Yet the right of resistance figures less as a concrete practice by which the constituting people exert their power on an ongoing basis and more as 
a regulative norm that is internalised by a legitimate regime in a way that encourages the appropriate degree of responsiveness (Pettit, 2012: 174). The overall picture bears close resemblance to the more moralised versions of liberal constitutionalism and indeed in a footnote Pettit aligns himself with Ronald Dworkin's 'partnership' conception of democracy understood as a joint project for the fulfilment of constitutionally enshrined public values (Dworkin, 1998; Pettit, 2012: 180).

Part of the problem concerns how Pettit understands political legitimacy. He suggests that although legitimacy is more appropriately thought of as a matter of degrees than an 'on-off' concept, there is a certain 'threshold' at which it makes sense to say a regime is legitimate. The difficulty comes with how this binary categorisation translates into Pettit's discussion of the ethics of political action. Here, we are presented with a stark choice between engagement 'within the system' to challenge a legitimate regime or else more militant 'resistance' and 'revolution' against an illegitimate regime (with the caveat that an illegitimate regime may be made legitimate by working through accepted channels) (Pettit, 2012: 136-140). However, if legitimacy is indeed a spectral concept, as Pettit suggests, we should expect that while some elements of a regime will be responsive to democratic control, others will be exclusionary, corrupt or otherwise illegitimate and thus require intervention from the outside. Arguably, the very existence of states imposes an inescapable degree of domination given the scope for the arbitrary exercise of power by rulers, no matter how optimal the constitutional rules in place (Vatter, 2015). Crucially, we should expect that within any pluralistic political community, the very terms of legitimacy - what counts as 'equally shared control' over government, in Pettit's terms - will themselves be contested, with new claims to equality emerging that seek to challenge and overturn existing norms. If citizens lose out in a political decision - whether it be through electoral politics or a judicial verdict - they will not be able to regard it as a matter of 'tough luck' - and hence legitimate - if the prevailing ideal of equal citizenship is in dispute (Pettit, 2012: 153, 139).

\section{Bellamy and Parliamentary Republicanism}

In contrast to Pettit's focus on adjudicative processes, parliamentary republicans, such as Richard Bellamy, give primacy to representative electoral institutions: the polity's regime of rights is to be shaped by equal participation by citizens in elections under a competitive party system based on one person, one vote. Bellamy's work places particular emphasis on the contested nature of rights across their content, weight and distribution, linking political disagreements about rights to legitimate differences between ideological perspectives within a modern, pluralistic society. Representative institutions are to be preferred over courts on the basis that they respect individual autonomy by empowering citizens to influence decisions on rights on equal terms with others. Under this perspective, courts themselves are potential sources of domination that may reflect the arbitrary views of an elite minority of judges against the democratic will of the majority. This normative case for parliamentary decisionmaking is linked to pragmatic claims about the institutional benefits of representative bodies in bringing to bear a wide range of knowledge, ideas and opinions on rights, in contrast to the insulated deliberations of judges (Bellamy, 2007).

This approach addresses some of the democracy-based concerns with juridical republicanism. Part of the appeal of majoritarian institutions, for parliamentary republicans, is that they can 
provide a check on the rights of wealthy and powerful minorities by opening the official regime of rights to ongoing challenge and revision (Bellamy, 2007; Waldron, 1999). In addition, Bellamy's 'constitutive' account of citizenship emphasises that political rights of participation - and the procedural values that ground them - will always be susceptible to challenge so that constitutionalism becomes an open, forward-looking process. However, the preoccupation of parliamentary republicans with judicial authority has the misleading implication that this is the most important source of elite domination, neglecting the fact that the wealthy and powerful also defend their interests through the ordinary legislative process. Bellamy aligns his approach with the Rousseauian tradition, in distinction to Pettit, but drops Rousseau's insights on how representative legislatures can distort the process of collective willformation. An over-riding concern with the formal distribution of constitutional powers overlooks how political equality is compromised by less visible and more insidious relations of power through monied control of electoral politics and inegalitarian social structures that undermine the formal equality of citizenship $($, 2015). The emphasis is on social and political reform through the 'prevailing procedures' of the constitution with little mention of the materialist and socially embodied aspects of popular politics outside the official order (Bellamy, 2007: 174). Bellamy's accompanying account of the political virtues, in terms of a patient electoral politics of negotiation, bargaining and compromise - animated by the civic humanist injunction to 'hear the other side' - offers only a partial picture of civic engagement, which elides the more antagonistic modes of claim-making frequently necessary to overcome entrenched inequalities of power (Bellamy, 2012: 460).

Bellamy is sceptical about the role of populist politics which, he suggests, risks substituting narrow, sectional claims for the authoritative decisions of representatives absent the discipline of electoral coalition-building and compromise. But this relies upon a misplaced faith in representative politics as somehow self-policing (Goldoni, 2014). In its determination to protect the integrity of laws by parliament from the counter-majoritarian difficulty of judicial review, parliamentary republicanism fails to appreciate the role of more collective and democratic modes of contestation. For while elections and parliamentary law-making clearly have an important role to play in the extension of freedom and opportunity, the 'prevailing procedures' cannot be relied upon as a source of renewal: alternative more performative and experimental modes of participation are frequently indispensable for the articulation of rights. While historically this was true of women, workers and racial minorities, today it arguably applies to prisoners, irregular migrants, the homeless and others who lack access to formal democratic citizenship or else lack the public standing necessary to exercise it effectively.

\section{Populist Citizenship and Rights}

From a historical perspective, it is surprising that neo-Roman theorists have had so little to say about participation beyond the confines of formal constitutionalism, given that many of the canonical rights we enjoy today are the achievement of past political uprisings, with the defining epochs of modern republican thought irrevocably shaped by their revolutionary context. Notably, early popular movements, such as the English Levellers, developed a staunchly republican theory of resistance to arbitrary power within the context of the English civil war linked to the idea of the people as ultimate custodians of liberty (Glover, 1999). Under this picture, rights-bearers are self-assertive political agents with the capacity to 
apprehend injustice and take independent action to stop it. I propose that Joel Feinberg's $(1970,1973)$ influential analysis of rights as 'claims' provides a fruitful pathway into thinking about a more assertive politics of rights faithful to this rebellious tradition. In what remains of this article, I set out the pertinent features of Feinberg's analysis, offer an account of populist citizenship and conclude with an illustration from contemporary movements for a right to housing.

Feinberg's writings on rights notably focus on the active, verbal form of the term claim in contrast to a more static focus on its possessive nounal form. Feinberg draws on the canonical analysis of rights by the jurist Wesley Hohfeld. While Hohfeld was primarily concerned with the classification of legal rights, his analysis drew attention to the political character of 'claimrights', which, in contrast to 'liberties', denote a relationship between two agents. Significantly, Hohfeld notes that a claim correlates to a duty owed to the claim-right-holder and that it is held against the bearer of the correlative duty (Hohfeld, 1919). In recent work, the duties that correlate to claimrights have been usefully described as directed duties, being owed to a specific agent in the person of the claim-right-holder, as distinct from non-directed duties, such as those of charity, that are not owed to anyone in particular (Sreenivasan, 2010). Feinberg offers an explanation of the moral significance of rights having the relational structure Hohfeld describes with reference to the upright, assertive and demanding set of attitudes and responses appropriate to the performance or non-performance of directed duties. Applying the insights of JL Austin, John Searle and other linguistic philosophers, Feinberg casts rights as a speech act. Paradigmatically, the phrase 'I have a right to $X$ ' is uttered by agent $A$ when $X$ is under threat by some other agent $B$ (Feinberg, 1980: 238). In these circumstances, the speech act is performed to protest and challenge the unjust behaviour of agent $B$ and call for support from 'enlightened' third parties in the political community - agents $\mathrm{C}$ - who recognise the binding moral authority of the claim. In this way, a right is a quintessentially political concept that defines relations of both solidarity and opposition (see also Flathman, 1976: 72; Shue, 1996: 14). It is apt to say that a right is held against the obligation-bearer since in practice the addressee of a right is more often than not a rights-withholder who will be most hostile to the recognition of just claims, as with the government curbing political criticism, the employer denying their workers a living wage or the patriarchal husband. The performative claiming of a moral right in this context frames the addressee as someone who is unjust and to be opposed and calls on the people to aid enforcement through various means which may include protests, petitions, strikes, vigils, boycotts and an array of other movement tactics. 5

To conceive of oneself as a bearer of moral rights can have emboldening psychological effects. As Feinberg (1980: 147) puts it, rights are not 'gifts or favors' like charity, to which the appropriate response is gratitude, but something that, in appropriate circumstances, 'a man can stand on ... without embarrassment or shame'. This standing is linked to the respect persons enjoy as 'maker of claims'; as persons with authority over their interests with the power to author and respond to binding moral demands upon others. Stephen Darwall has termed this form of respect 'recognition respect' in contrast to 'appraisal respect', which is owed to persons based on some contingent social achievement or characteristic, such as athletic skill or generosity (Darwall, 2006: 122-126). Within hierarchical social systems, those deemed inferior on the basis of race, class, sexuality or some other socially ascribed feature may acquiesce to narratives that denigrate their status leading them to accord recognition 
respect to those above them in the hierarchy without according the same respect to themselves. The path to emancipation involves the application of recognition respect to oneself - seeing oneself as a person with interests, desires and purposes that count morally speaking and someone capable of acting to defend them.

In his study of an Appalachian mining town, John Gaventa (1982: 257) describes this process of overcoming domination as 'conscientization', in which the powerless 'develop their own notions of interests and actions, and themselves as actors'. Individual feelings of humiliation and powerlessness are overcome through a collective diagnosis of the particular social injustice one suffers from in solidarity with others similarly positioned in social relations. A political culture of rights, under the Feinbergian perspective, has a strong anti-paternalistic logic that recalls how republicans describe a non-dominating polity. The self-respect conferred by rights consists in the confidence and self-esteem that comes with being able to stand tall and look others in the eye (Pettit, 2012: 84). Juridical and parliamentary republicans tend to associate the idea of standing with the possession of formal citizenship rights. Yet we should also note the value of a wider political practice of moral rights, which sanctions ongoing challenges to the limits and exclusions of formal citizenship from the outside. A critical practice of moral rights is one where individuals see themselves as having a particular standing as makers of claims to take the initiative, organise and demand treatment against the powerful even in the absence of institutional channels of redress through appeal to the morality of an enlightened subjectivity.

Where injustice is entrenched, forms of political action that embrace struggle and antagonism may be necessary. This requires a set of political virtues markedly different from the institutionalised forms of deliberation, negotiation and compromise characteristic of official citizenship. The essential elements of this conception of civic virtue are familiar from Machiavelli who saw a productive role for social conflict in political life, noting the vital role of agitation by the 'populi' in curbing the ambition and greed of the 'grandi' (McCormick, 2011). More recent work has contributed the idea that political conflict can have a beneficial epistemic role in challenging social consensus and bringing new perspectives to bear into democratic discussion (Hampshire, 2000; Sunstein, 2003). The normative flexibility of the discourse of rights - based on abstract principles of equality, freedom and human dignity serves an important role here, sanctioning moral innovation by excluded groups who extend and deepen core principles, rethinking the basis of equal citizenship through 'rights work' (Plummer, 2006). Through self-education, dialogue and experimental learning, groups and classes marginalised from official politics generate new critiques and understanding, which in turn proliferate and feed into the formal public sphere (Mansbridge, 1994). In this way, movement politics combines both the editorial and authorial dimensions of republican citizenship. It is a form of collective contestation through which groups affected by a particular injustice compel a reconsideration of the polity's regime of rights by means of disruption and unsettlement, generating new moral norms and perspectives with which to critique dominant arrangements.

The 'people' in this context refers not to the role citizens play in elections and other constitutionally mediated forms of representation. Nor does it refer (necessarily) to the entire demos or to a political majority. Instead, populist citizenship references the 'constituent' body of the people acting outside official structures in opposition to its 'constituted' embodiment 
within state institutions whose legitimacy is called into question. As Jason Frank put it in his study of constituent power in post-revolutionary America, 'the people are a political claim ... not a pre-given, unified, or naturally bounded empirical entity' (2010: 3). In Jacques Rancière's (2004b: 26) terms, it is the part of the people that has 'no part' and thus goes unheard and uncounted in the ordinary course of institutional politics. This idea traces its roots to the twofold Aristotelian notion of the people as both the demos and the poor or popular classes who are excluded from taking part in government. The challenge for the unseen and unheard is how to make the domination they endure visible and become recognised as legitimate partners in political debate (Rancière, 2004a). This typically involves the appropriation of public spaces, such as squares and parks, from which they are symbolically excluded, along with those spaces conventionally designated as 'apolitical' and 'private', such as factories or lunch counters. Rancière (2004a: 303 ) tells the story of a woman in France in 1848 who turned up to present herself for election at a time when women did not have the vote. Through this action, she brought to attention the moral contradiction between the universal principles of political rights proclaimed by the French state and her own disenfranchisement: her physical appropriation of a prohibited space broadcast a call to the people to transform exclusionary political institutions through campaigning and reform. Such actions manifest the performative Arendtian dimension of politics as 'appearance' in which the unseen and unheard 'make their appearance explicitly' and enter the stage as political subjects (Arendt, 2003: 199). In the next and final section, I provide an illustration of the dynamics of populist republican claim-making in the form of contemporary political struggles for housing.

\section{Making Claim to the Right to Housing}

In Europe and the United States, the years following the 2008 financial crisis have seen a wave of home repossessions and evictions with a vast increase in the number of people without access to secure, adequate accommodation thanks to unemployment, insufficient wages and cuts to housing support by governments implementing austerity measures. This process has fuelled the rapid acceleration of gentrification whereby working class and ethnic minority communities are priced out of desirable inner city areas (Harvey, 2013). In response, a number of movements have emerged that use a political strategy of squatting, rent strikes and eviction resistance designed to meet housing needs directly, force the question of housing into public debate and pressure the authorities to act. In London, the Focus E15 campaign was started after a group of young and expectant mothers had been evicted by the local council from a shelter for homeless women so that the property could be sold to a private developer for conversion into luxury flats. Facing the prospect of being rehoused in cities hundreds of miles from the communities in which they grew up, the group began a campaign of high-profile occupations of properties alongside direct action casework, geared to helping particular individuals and families in need find accommodation (Lupton, 2014). After a high-profile series of occupations, the Focus E15 mothers were told their eviction notices were a 'mistake' and that the council would help house them locally. However, the group continued to build support around the lack of affordable housing in London and have acted in solidarity with other groups campaigning in the capital (Chakraborty, 2014). Focus E15 is just one of a number of local housing campaigns in countries affected by the financial crisis, with groups that share similar strategies, understandings and objectives active in the United States, Germany, Greece, Portugal and (most notably) Spain where they have linked up with 'Occupy', the Indignados and the wave of anti-austerity movements committed to 
popular participatory politics (della Porta, 2014; Hoover, 2015). The campaigns are led by those most directly affected by insecure housing, often young, working class and Black mothers. Through the occupation of land and property, these groups 'make their appearance directly' as political actors, broadcasting the injustice of an economic system in which homelessness and destitution co-exist with vast numbers of empty properties. In so doing, they discover their own political voice and agency, constituting themselves as citizens whose opinions and interests count in public debate and defining relations of solidarity and opposition. The claim to housing is frequently based on a populist appeal to the people as third parties (the '99\%') outside the elite-controlled structures of political institutions. From the populist perspective, the threat to housing rights comes not from discriminatory majorities, but from the oligarchic ' $1 \%$ ' of financiers, politicians and property developers who are charged with the corruption of the public good in the interests of a propertied elite (Todd, 2014). The claimed right to housing has a dualistic moral character. As these popular movements interpret it, it serves a vital individual need for secure accommodation, but also a social interest in a tolerant, diverse and inclusive civic life in which all social groups get to shape and inhabit the city and not just those privileged by race and class. Notably, these movements do not simply affirm the social democratic conception of housing rights found in international law and mainstream political discourse; they give substance to a more transformative conception based on the de-commodification of housing alongside communal ownership and self-management (Hoover, 2015).

The political leverage of housing movements comes from their physical occupation of housing and land, which stands as a direct challenge to private property rights. The formal rights to equal citizenship that protect free speech and association are a necessary precondition for this type of action since without them activists would face far worse repression and punishment. However, rights to equal citizenship are by themselves insufficient to empower all groups with voice and influence. Direct action is one of the few avenues open to the homeless who, as a group, face substantial formal and informal obstacles to participation. Not only does electoral participation usually require a place of residence, but the homeless may lack access to media, education and other resources that would empower them to participate effectively. Furthermore, there is a social stigma attached to the condition of homelessness, buttressed by a moralised public discourse that emphasises the 'personal responsibility' of the homeless person at the expense of systemic causes (Young, 2010: 1-74). Concerted political action by the homeless overturns the perception of them as needy victims and makes them visible within public debate, building self-confidence and the willingness to participate in democratic politics.

In some countries, squatting, which was previously seen as an illegitimate fringe activity, has come to be viewed as a legitimate response to exclusion and deprivation in the contemporary social and economic context in the manner that strikes, boycotts, sit-ins - and other forms of direct action that were previously illegal - eventually became established as a legitimate tool of dissent (Jacobo et al., 2012). By pushing at the boundaries of acceptable dissent, populist citizenship thus has an important role to play in broadening the forms that political participation can take and the sovereignty of the people is expressed. A final point concerns the role of popular politics in the cultivation of civic virtue. Housing activists frequently aspire to contest relations of arbitrary power on the micro-level within their temporary selfmanaged communities, which function on a nonhierarchical and participatory basis. Through 
occupation, skills of practical organisation, discussion and decision-making are learned and practised and participants develop their own self-confidence along with a moral sensibility to the perspectives of others (Rameau, 2008). While the notion of civic virtue, as it is traditionally presented in republicanism, can have a conservative set of resonances as something coercively promoted by the state to mould citizens who can uphold existing institutions, from a populist perspective, civic virtue is something cultivated not by the state but by citizens themselves, through their own associations and practices, with the aim not simply to preserve institutions but to transform them in a more just direction (Gourevitch, 2015).

\section{Conclusion}

Republican political theory offers a distinct approach to thinking about the nature of rights and how they are created and upheld that emphasises civic participation and contestation. Juridical republicanism focuses on individualised forms of contestation through legal avenues of redress as a check on majority tyranny. This restricts the democratic power of majorities in potentially dominating ways and risks constraining the terms of critique to the status quo. Parliamentary republicanism sees an important authorial role for citizens in shaping the polity's regime of rights within a framework of electoral competition and coalition-building. However, its preoccupation with the counter-majoritarian difficulty of judicial review leads it to neglect other potential sources of elite power, and it lacks an account of how political change takes place outside the prevailing procedures of constitutionalism. The account of populist citizenship I have given addresses this oversight through attention to claim-making practices outside and against the state. Under the populist account, rights are tools of political action that constitute their bearers as doers and actors, identifying an unjust adversary and calling on the people for support through an egalitarian appeal to the common good. Undoubtedly, the law has a vital role to play in making rights effective and secure through the institutionalisation of schemes of protection, provision and official remedy. However, there are compelling reasons not to depend on the law and state institutions as custodians of our freedom, so relinquishing our capacities for critical moral thought and judgement to lawyers, judges and political officials. A populist approach encourages the perspective that rights are historically contingent political victories that may be subject to reversal and retreat unless maintained through a readiness to organise and mobilise in solidarity with others. Given the perennial limits of politics, about which republicans are so eloquent, populist citizenship has a vital role to play in political renewal, creating and securing rights for new political subjects whose claims fall outside the dominant values and procedures of constitutional legitimacy.

\section{Notes}

1 See Pettit (1997) and his more recent work (Pettit, 2012). Cass R. Sunstein (1988) is another prominent advocate of juridical republicanism.

2 Bellamy (2007). Jeremy Waldron's (1999) advocacy of legislative decision-making on rights likewise rests on a republican commitment to self-government. While both theorists argue for democratic oversight 15 of rights, Bellamy focuses more on electoral politics and Waldron on legislative deliberation ( , 2015).

3 Some argue that neo-republicans exaggerate their theoretical opposition to liberalism and that the similarities between the two traditions are more important than the differences (Larmore, 2003; Patten, 1996). That there are important commonalities is to be expected given the historical overlaps and continuities between the two traditions. 
4 Leaving aside the sub-category of 'group' rights that attach themselves to nations, cultural minorities and other collective entities.

5 To be clear, it is not the insistence with which individuals push their claims that makes them morally correct, but their moral correctness that gives them the standing to claim insistently.

\section{References}

Abellán J, Sequera J and Janoschka M (2012) Occupying the\# Hotelmadrid: A Laboratory for Urban Resistance. Social Movement Studies 11 (3-4): 320-326.

Aitchison, G (2015) Rights, Citizenship and Political Struggle. European Journal of Political Theory. Epub ahead of print. DOI: 10.1177/1474885115578052.

Arendt H (2003) The Human Condition. Chicago, IL: University of Chicago Press.

Beitz CR (2009) The Idea of Human Rights. Oxford: Oxford University Press. Bellamy R (2007)

Political Constitutionalism: A Republican Defence of the Constitutionality of Democracy. Cambridge: Cambridge University Press.

Bellamy R (2012) Rights as Democracy. Critical Review of International Social and Political Philosophy 15 (4): 449-471. Brown W (2004) 'The Most We Can Hope For ...': Human Rights and the Politics of Fatalism. The South Atlantic Quarterly 103 (2): 451-463. Chakraborty A (2014) The Guardian. Available at: http://www.theguardian.com/commentisfree/2014/sep/23/ real-politics-empty-londonhousing-estate (accessed 10 June 2015).

Dagger R (1997) Civic Virtues: Rights, Citizenship, and Republican Liberalism. New York: Oxford University Press.

Darwall SL (2006) The Second-Person Standpoint: Morality, Respect, and Accountability. Cambridge, MA: Harvard University Press. della Porta D and Mattoni A (eds) (2014) Spreading Protest: Social Movements in Times of Crisis. Colchester: ECPR Press.

Douzinas C (2000) The End of Human Rights: Critical Legal Thought at the Turn of the Century. Oxford: Hart Pub. Dworkin R (1977) Taking Rights Seriously. Cambridge, MA: Harvard University Press.

Dworkin R (1998) The Partnership Conception of Democracy. California Law Review 86: 453. Feinberg J (1970) The Nature and Value of Rights. The Journal of Value Inquiry 4 (4): 243-260. Feinberg J (1973) Social Philosophy, vol. 92. Englewood Cliffs, NJ: Prentice-Hall.

Feinberg J (1980) Rights, Justice, and the Bounds of Liberty: Essays in Social Philosophy. Princeton, NJ: Princeton University Press.

Flathman R (1976) The Practice of Rights. London: Cambridge University Press.

Fox Piven F (2006) Challenging Authority: How Ordinary People Change America. Lanham, MD: Rowman \& Littlefield Publishers.

Frank J (2009) Constituent Moments: Enacting the People in Postrevolutionary America. Durham, NC: Duke University Press.

Gaventa J (1982) Power and Powerlessness: Quiescence and Rebellion in an Appalachian Valley. Urbana, IL: University of Illinois Press.

Gewirth A (1982) Human Rights: Essays on Justification and Applications. Chicago, IL: University of Chicago Press.

Glendon MA (2008) Rights Talk: The Impoverishment of Political Discourse. New York: Simon \& Schuster.

Glover SD (1999) The Putney Debates: Popular Versus Élitist Republicanism. Past \& Present 164: 47-80. 
Goldoni M (2014) Political Constitutionalism and the Question of Constitution-Making. Ratio Juris 27 (3): 387-408.

Gourevitch A (2014) From Slavery to the Cooperative Commonwealth: Labor and Republican Liberty in the Nineteenth Century. New York: Cambridge University Press.

Gourevitch A (2015) Solidarity and Civic Virtue. Paper presented at the 'Reclaiming Republicanism' Conference, University of Oxford, Oxford, 27 June. 16

Habermas J (1994) Human Rights and Popular Sovereignty: The Liberal and Republican Versions. Ratio Juris 7 (1): 1-13.

Hampshire S (2000) Justice Is Conflict, vol. 5. Princeton, NJ: Princeton University Press.

Harvey D (2013) Rebel Cities: From the Right to the City to the Urban Revolution, 2nd edn. London: Verso Books.

Hohfeld W (1919) Fundamental Legal Conceptions: As Applied in Judicial Reasoning (ed. Cook WW). New Haven, CT: Yale University Press.

Hoover J (2015) The Human Right to Housing and Community Empowerment: Home Occupation, Eviction Defence and Community Land Trusts. Third World Quarterly 36 (6): 1092-1109.

James S (2003) VII - Rights as Enforceable Claims. Proceedings of the Aristotelian Society 103: 133-147.

Krause SR (2013) Beyond Non-Domination Agency, Inequality and the Meaning of Freedom. Philosophy \& Social Criticism 39 (2): 187-208.

Laborde C (2008) Critical Republicanism: The Hijab Controversy and Political Philosophy. Oxford: Oxford University Press. Laborde C and Maynor J (2008) The Republican Contribution to Political Theory. In: Laborde C and Maynor J (eds) Republicanism and Political Theory. Malden, MA: Blackwell Publishing, pp.1-30.

Larmore C (2003) Liberal and Republican Conceptions of Freedom. Critical Review of International Social and Political Philosophy 6 (1): 96-119.

Lupton V (2014) Power and Solidarity at the Grassroots. Available at: https://opendemocracy.net/5050/victoria- lupton/power-and-solidarity-at-grassroots (accessed 5 June 2015).

McCormick JP (2011) Machiavellian Democracy. Cambridge: Cambridge University Press.

Macpherson CB (1969) The Political Theory of Possessive Individualism. Oxford: Clarendon Press.

Mansbridge J (1994) Using Power/Fighting Power. Constellations 1 (1): 53-73.

Marmor A (2015) What Is the Right to Privacy? Philosophy \& Public Affairs 43 (1): 3-26.

Nicol D (2010) The Constitutional Protection of Capitalism. Oxford: Bloomsbury Publishing. Nozick R (1974) Anarchy, State, and Utopia, vol. 5038. New York: Basic Books.

O'Neill O (2000) Women's Rights: Whose Obligations? In: O'Neill O (ed.) Bounds of Justice. Cambridge: Cambridge University Press, pp.97-112.

Patten A (1996) The Republican Critique of Liberalism. British Journal of Political Science 26(1): 25-44.

Pettit P (1997) Republicanism: A Theory of Freedom and Government: A Theory of Freedom and Government. Oxford University Press.

Pettit P (2004) Depoliticizing Democracy. Ratio Juris 17 (1): 52-65.

Pettit P (2012) On the People's Terms: A Republican Theory and Model of Democracy. Cambridge: Cambridge University Press.

Plummer K (2006) Rights Work: Constructing Lesbian, Gay and Sexual Rights in Late Modern Times. In: L Morris (ed.) Rights: Sociological Perspectives. Abingdon: Routledge, pp.152-167. 
Rameau M (2008) Take Back the Land: Land, Gentrification and the Umoja Village Shantytown. Miami, FL: Nia Press. Rancière J (2004a) Disagreement: Politics and Philosophy. Minneapolis, MN: University of Minnesota Press.

Rancière J (2004b) Who Is the Subject of the Rights of Man? The South Atlantic Quarterly 103 (2): 297-310.

Rawls J (1971) A Theory of Justice. Cambridge, MA: Belknap Press.

Raz J (2010) Human Rights without Foundations. In: J Tasioulas and S Besson (eds) The Philosophy of International Law. Oxford: Oxford University Press, pp.321-388. Roberts A (2015) A Republican Account of the Value of Privacy. European Journal of Political Theory 14: 320-344.

Shue H (1996) Basic Rights: Subsistence, Affluence, and US Foreign Policy. Princeton: Princeton University Press. S

kinner Q (1986) The Paradoxes of Political Liberty. The Tanner Lectures on Human Values 7: 225-250.

Skinner Q (1998) Liberty Before Liberalism. Cambridge: Cambridge University Press.

Southwood N (2015) Republican Justice. Critical Review of International Social and Political Philosophy 18 (6): 669-678.

Sreenivasan G (2010) Duties and Their Direction. Ethics 120 (3): 465-494.

Sunstein CR (1988) Beyond the Republican Revival. The Yale Law Journal 97 (8): 1539-1590.

Sunstein CR (2003) Why Societies Need Dissent. Cambridge, MA: Harvard University Press. Tilly C (2012) Social Movements, 1768-2012. Boulder, CO: Paradigm Publishers.

Todd J (2014) openDemocracy, December. Available at: https://opendemocracy.net/ourkingdom/joseph-todd/ housing-crisis-deficit-in-democracyoccupydemocracy (accessed 10 June 2015).

Vatter M (2015) Political Ontology, Constituent Power, and Representation. Critical Review of International Social and Political Philosophy 18 (6): 649-686.

Waldron J (1999) Law and Disagreement. Oxford: Clarendon Press. Waldron J (2014) Nonsense Upon Stilts (Routledge Revivals): Bentham, Burke and Marx on the Rights of Man. Abingdon: Routledge.

Winters JA (2011) Oligarchy. Cambridge: Cambridge University Press. Young IM (2010) Responsibility for Justice (Reprint edition). New York: Oxford University Press. 